\title{
PREDIKSI FINANCIAL DISTRESS PADA BUMN DALAM RANGKA MENILAI KINERJA PERUSAHAAN PEMERINTAH
}

\author{
Barbara Gunawan \\ Universitas Muhammadiyah Yogyakarta \\ barbaraqunawan@yahoo.co.id \\ Diesy Nurfithriyani \\ Universitas Muhammadiyah Yogyakarta \\ diesynurfithriyani@gmail.com
}

\begin{abstract}
Abstrak
Badan Usaha Milik Negara (BUMN) memiliki peran dalam peningkatan pendapatan negara melalui pembayaran pajak dan setoran deviden perusahaan, namun permasalahan yang dihadapi saat ini adalah hutang yang dimiliki BUMN semakin meningkat dikarenakan komitmen pemerintah pada pembiayaan perusahaan kurang optimal sehingga memungkinkan perusahaan berada pada kondisi kesulitan keuangan. Penelitian ini bertujuan untuk memprediksi kesulitan keuangan atau financial distress perusahaan BUMN bidang industri pengolahan selama 2014-2018 dan menganalisis kestabilan kinerja perusahaan pada tahun tersebut. Prediksi financial distress pada penelitian ini menggunakan teknik analisis diskriminan dengan menggunakan 5 model yaitu model altman, zmijewski, springate, grover, dan fulmer. Hasil penelitian menunjukan bahwa model yang menghasilkan perusahaan sehat adalah model zmijewski dan fulmer dengan presentase $100 \%$ sehat, disusul dengan grover dengan presentase sehat $68 \%$, sedangkan 2 model lainnya didominasi kebangkrutan dengan presentase $60 \%$ perusahaan bangkrut pada model altman dan $76 \%$ bangkrut pada model springate. Adapun tingkat kesehatan perusahaan dilihat dari 5 model tersebut berturut turut yaitu perusahaan SMBR, SMGR, KRAS, KAEF, dan INAF.
\end{abstract} kebangkrutan

Kata kunci: kesulitan keuangan, kinerja perusahaan,

\section{PENDAHULUAN}

Anggaran pendapatan dan belanja negara disusun sebagai pedoman dalam mengalokasikan pendapatan dan belanja negara. APBN dibuat supaya pemerintah memiliki gambaran untuk satu tahun mendatang tentang pendapatan yang harus diterima oleh negara dan belanja yang harus dipenuhi untuk kebutuhan negara, sehingga APBN yang sudah disusun tersebut diharapkan dapat meningkatkan ekonomi, kemakmuran masyarakat, dan kesempatan kerja. 
BUMN mempunyai peran yang cukup signifikan dalam meningkatkan APBN, hal tersebut dibuktikan dengan terus meningkatnya kontribusi BUMN terhadap APBN. kontribusi tersebut berupa pembayaran pajak serta setoran deviden seperti tampak pada Gambar 1. Hal demikian tentunya sangat menguntungkan bagi pemerintah khususnya kementerian keuangan sebagai regulator perekonomian Indonesia. Pada tahun 2019 kontribusi pajak diprediksi mencapai Rp.347.000.000.000.000,- dan kontribusi deviden sebesar Rp.38.000.000.000.000.- diakui sebagai target yang berat bagi BUMN dikarenakan komitmen pemerintah terhadap BUMN tidak seluruhnya mendapatkan pembiayaan dari pemerintah maka cara lain dalam memenuhi kebutuhan BUMN adalah dengan pembiayaan hutang.

Hutang tersebut yang sekarang menjadi beban bagi para agen di BUMN. Pasalnya, defisit anggaran masih dianggap proporsional bagi beberapa kalangan, akan tetapi tentunya menjadi beban besar bagi BUMN. Seperti yang dikemukakan oleh Deputi Bidang Restrukturisasi dan Pengembangan Bisnis Kementerian BUMN, peningkatan hutang BUMN tersebut dikarenakan kurangnya modal yang diberikan untuk beberapa proyek yang dikerjakan BUMN. Namun, hutang yang dihasilkan BUMN tidak perlu ditakutkan karena sejatinya pertumbuhan utang tersebut dibarengi dengan pertumbuhan aset yang lebih tinggi (CNN 2018).

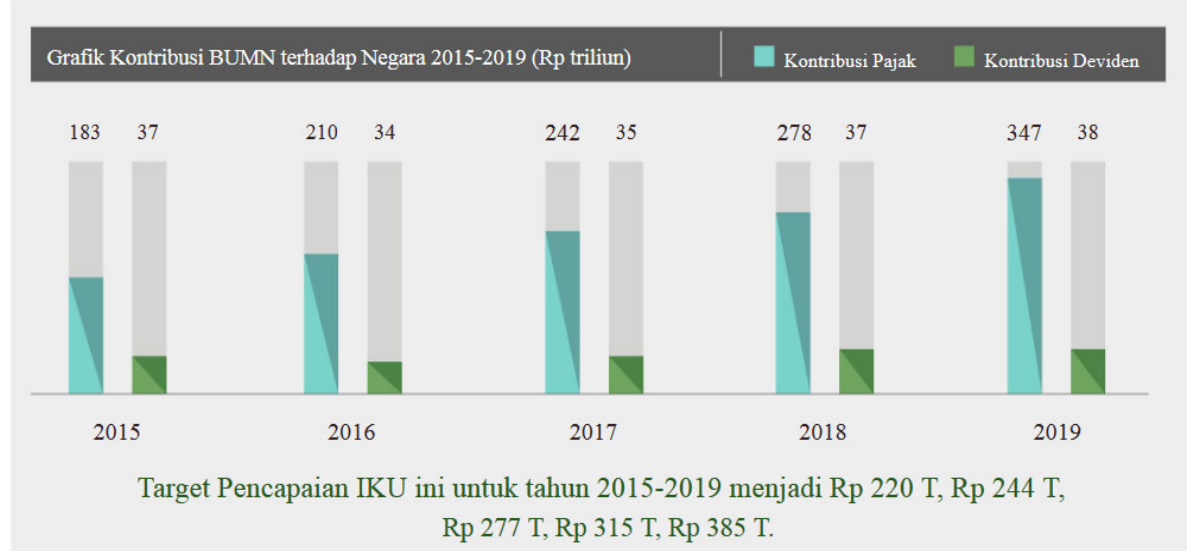

\section{Gambar 1 Grafik Kontribusi BUMN terhadap Negara} Sumber: Renstra Kementerian BUMN

Hutang merupakan salah satu permasalahan yang ada diperusahaan. Selanjutnya permasalahan dalam keuangan menyebabkan kegagalan dalam perusahaan. Seperti yang dituturkan oleh Dinarjito (2018) salah satu masalah keuangan yang dialami perusahaan adalah tidak terpenuhinya hutang kepada kreditor atau perusahaan mengalami pailit sehingga tidak dapat membayar kewajiban kepada kreditor. Meningkatnya hutang berarti mewaspadai perusahaan pada ambang kebangkrutan. Oleh karena itu, 
dalam menunjang keberhasilan kinerja pemerinatah, BUMN memberikan andil dalam menstabilkan perekonomian Indonesia, ketika BUMN mempunyai hutang atau memberikan kinerja kurang baik maka pemerintah harus tanggap dan merespon dengan proaktif.

Berdasarkan uraian tersebut, penelitian ini bertujuan untuk mengukur apakah BUMN mampu stabil atau bahkan berada pada kondisi financial distress (kesulitan keuangan) sehingga akan ada penurunan pendapatan perpajakan ketika BUMN berada pada kondisi distress, hal tersebut akan berdampak pada Anggaran Pendapatan dan Belanja Negara (APBN). Hasil dari penelitian ini diharapkan menjadi peringatan dini bagi seluruh elemen perusahaan baik BUMN selaku agen maupun pemerintah selaku prinsipal dalam mencegah terjadinya kebangkrutan pada perusahaan.

\section{TELAAH LITERATUR}

\section{Teori Keagenan}

Teori Agensi adalah hubungan antara agen (manajer) dan prinsipal (investor). Prinsipal selaku pemegang kepentingan memberikan mandat kepada agen untuk menjalankan tugas menejerial (operasional perusahaan), termasuk otorisasi pengambilan keputusan dalam perusahaan (Riswan dan Affandi 2014). Jika agen tidak menjalankan tugas keagenannya atau prinsipal tidak percaya akan pekerjaan agen secara optimal maka akan terjadi konflik sehingga memicu biaya keagenan. Salah satu permasalah yang sering terjadi di suatu perusahaan antara agen dan prinsipal adalah adanya asimetri informasi (Bestari dalam Ikhsan dan Ishak 2014). Asimetri informasi adalah akses informasi manajer atas prospek perusahaan yang tidak dimiliki oleh pihak luar.

Secara moral, agen sebagai manajer bertanggung jawab untuk mengoptimalkan keuntungan para pemilik, sebagai imbalannya akan medapatkan kompensasi sesuai dengan perjanjian dalam kontrak, namun kadang kala agen menjalankannya menyeleweng dari yang seharusnya seperti tindakan mengedepankan kepentingkan pribadi dari pada kepentingan organisasi sehingga terjadi konflik antar keduanya dan menyebabkan ketidakcocokan sebagai partner pelaku ekonomi dan berdampak pada ketidakstabilan perusahaan.

Dalam penelitian ini pemerintah berperan sebagai prinsipal karena pemodal pada perusahaan BUMN, sedangkan BUMN adalah agen penggerak perusahaan untuk memfasilitasi masyarakat dalam rangka membantu terselenggaranya program-program pemerintah.

\section{Financial Distress}

Financial distress atau kondisi kesulitan keuangan adalah keadaan dimana perusahaan berada dalam ambang kebangkrutan atau likuidasi (Luciana dalam Dinarjito 2018). Keadaan ini dipicu oleh gagalnya 
manajemen dalam mengelola perusahaan atau gagalnya perusahaan dalam menghasilkan laba yang tinggi. Perusahaan yang mengalami financial distress akan dihadapkan oleh beberapa kondisi diantaranya (Gunawan et al. dalam Anggraini 2017):

a. perusahaan mengalami kegagalan pembayaran kembali hutang yang sudah jatuh tempo.

b. atau perusahaan berada dalam kondisi tidak solvable.

Gejala financial distress harus ditanggapi sedini mungkin oleh manajemen supaya menjadi evaluasi sebelum terjadinya kebangkrutan. Kebangkrutan dapat diprediksi dengan melihat kinerja keuangan perusahaan dari berbagai aspek baik aspek likuiditas, profitabilitas, maupun manajemen laba. Namun, masalah financial distress tidak bisa dihindari oleh perusahaan, tetapi risiko tersebut dapat dicegah dan diminimalisir kerugiannya, tentunya dengan manajemen yang baik melalui operasional perusahaan sehingga manajer dapat tanggap dalam memprediksi suatu fenomena kebangkrutan.

\section{Analisis Model Prediksi Kebangkrutan}

Teknik analisis yang dapat digunakan untuk mengukur tingkat kebangkrutan perusahaan yaitu: 1) Teknik Analisis Diskrminan, yaitu teknik analisis yang menggunakan multivariate discriminant analysis (MDA) sebagai model pengukurnya, 2) Teknik Analisis Logit, yaitu hasil perhitungannya menggunakan uji logit (Asnita dan Fuadi 2016). Teknik analisis tersebut mampu memprediksi kebangkrutan dengan tingkat akurasi yang berbeda-beda namun, tidak semua perusahaan cocok menggunakan semua model analisis kebangkrutan.

Teknik analisis diskiminan adalah salah satu teknik yang dapat digunakan dalam mengukur prediksi kebangkrutan, terdapat beberapa model prediksi yang dapat digunakan dalam menilai kebangkrutan perusahaan pada teknik ini seperti model altman, grover, fulmer, ohlson dan lainnya. Adapun analisis model prediksi kebangkrutan yang akan digunakan adalah sebagai berikut:

a. Model Prediksi Altman

Model multivariate discriminant analysis (MDA) adalah model prediksi yang dicirikan oleh altman untuk memprediksi kebangkrutan. Altman menggunakan lima jenis rasio laporan keuangan dalam menilai kebangkrutan, akan tetapi altman mengembangkan alternatif ini dengan menggantikan variabel $\mathrm{X}_{4}$ sebagai nilai pasar modal dengan nilai buku total hutang diubah menjadi perbandingan nilai buku saham dengan nilai buku total hutang (Wibisono et al. 2014). 
b. Model Prediksi Zmijewski

Zmijewski (dalam Rachaprima 2015) mengkritik metode penelitian sebelumnya dikarenakan terdapat bias pada teknik matched-pair sehingga kurang relevan digunakan. Kemudian dimunculkanlah model prediksi zmijzewski dengan fokus pada rasio likuditas, leverage, dan kinerja perusahaan (Dinarjito 2018).

c. Model Prediksi Springate

Model Springate adalah pengembangan prediksi kebangkrutan dari model altman dengan sama-sama menggunakan metode Multiple discriminant analysis (MDA) kemudian mengambil 4 rasio kauangan popular dari jumlah sebelumnya 19 rasio yang digunakan, sehingga menurut Gorgon L.V Springate hal ini dipergunakan agar bisa memprediksi perusahaan pailit atau tidak pailit (Lukman dan Ahmar 2015).

d. Model Prediksi Grover

Model Grover adalah model yang dikembangkan oleh Jeffrey S. Grover pada tahun 1968 dengan melakukan perubahan pada desain dan penilaian model altman yang kemudian menambah rasio-rasio keuangan baru. Jeffrey melakukan penelitian pada 70 perusahaan di tahun 1982-1996 dengan hasil 35 perusahaan sehat dan lebihnya mengalami kebangkrutan (Rachaprima 2015).

e. Model Prediksi Fulmer

Lukman dan Ahmar (2015) menyatakan bahwa model fulmer telah melakukan penelitian pada 60 perusahaan dengan metode step-wise multiple discriminant dengan mengevaluasi 40 rasio keuangan. Fulmer melaporkan $98 \%$ penelitiannya akurat pada perusahaan satu tahun sebelum gagal dan $81 \%$ akurat lebih dari satu tahun sebelum kebangkrutan.

\section{METODE PENELITIAN}

\section{Populasi dan Sampel}

Populasi yang digunakan dalam penelitian ini adalah BUMN bidang industri pengolahaan yang terdaftar di Bursa Efek Indonesia (BEI). Selain dipersyaratkan perusahaan telah mengungkapkan laporan keuangan secara lengkap pada periode penelitian, pemilihan sampel juga didasarkan pada laporan laba-rugi dan hutang perusahaan yang berjumlah besar. Berdasarkan persyaratan tersebut peneliti mengambil sampel pada 5 perusahaan bidang industri pengolahan yaitu: 
Tabel 1

Daftar Sampel Perusahaan

\begin{tabular}{rrl}
\hline NO & $\begin{array}{r}\text { KODE } \\
\text { SAHAM }\end{array}$ & \multicolumn{1}{c}{ NAMA PERUSAHAAN } \\
\hline 1 & KAEF & PT Kimia Farma (Persero) Tbk \\
2 & INAF & PT Indofarma (Persero) Tbk \\
3 & SMBR & PT Semen Baturaja (Persero) Tbk \\
4 & SMGR & PT Semen Indonesia (Persero) Tbk \\
5 & KRAS & PT Krakatau Steel (Persero) Tbk \\
\hline
\end{tabular}

\section{Data dan Teknik Pengumpulan Data}

Data yang digunakan untuk menunjang penelitian ini adalah data sekunder. Data sekunder dalam penelitian berupa laporan keuangan BUMN bidang Industri Pengolahan tahun 2014-2018 yang terdaftar di Bursa Efek Indonesia (www.idx.co.id). Teknik pengumpulan data yang digunakan peneliti adalah dokumentasi dan studi literatur.

\section{Model Penelitian}

Model analisis dalam penelitian ini menggunakan analisis deskriptif kuantitaif dengan memadukan beberapa rasio keuangan sehingga membentuk sebuah formula dalam model perhitungan financial distress seperti model altman, zmijewski, springate, grover, dan fulmer.

\section{Teknik Analisis}

Teknik analisis yang digunakan untuk mengkur kebangkrutan perusahaan yaitu teknik analisis diskriminan. Teknik analisis diskriminan adalah teknik analisis yang menggunakan multivariate discriminant analysis sebagai model pengukurnya. Penelitian ini menggunakan 5 model prediksi kebangkrutan dari teknik tersebut diantaranya:

a. Model Prediksi Altman

Prediksi kebangkrutan dengan model ini memiliki formula:

$$
\begin{aligned}
& \mathbf{Z}-\mathbf{S}=\mathbf{0 , 7 1 7 X 1}+\mathbf{0 , 8 4 7 X 2}+\mathbf{3 , 1 0 7 X 3}+\mathbf{0 , 4 2 0 X 4}+\mathbf{0 , 9 9 8 X 5} \\
& \text { Keterangan: } \\
& \text { X1 }=\text { Working Capital/Total Assets } \\
& \text { X2 }=\text { Retained Earning/Total Assets } \\
& \text { X3 }=\text { Earning before interest and tax/Total Assets } \\
& \text { X4 }=\text { Book Value of Equity/Book Value of Debt } \\
& \text { X5 }=\text { Sales/Total Assets }
\end{aligned}
$$


Tabel 2

Cutoff prediksi kebangkrutan Altman

\begin{tabular}{ccc}
\hline No & Cutoff & Keterangan \\
\hline 1 & $\mathrm{Z}<1,81$ & Bangkrut \\
2 & $1,81<\mathrm{Z}<2,675$ & Grey Area \\
3 & $\mathrm{Z}>2,675$ & Tidak Bangkrut/Sehat \\
\hline Sumber: Muslich, 2000 (dalam Wibisono et a/ 2014 )
\end{tabular}

b. Model Prediksi Zmijewski

Prediksi kebangkrutan dengan model ini memiliki formula:

$$
Z=-4,3-4,5 \times 1+5,7 \times 2-0,004 \times 3
$$

Keterangan:

$\mathrm{X} 1=$ Net Income/Total Asset (Return On Asset)

X2 = Total Debt/Total Asset (Debt Ratio)

$\mathrm{X} 3=$ Current Asset/Current Liabilities (Current ratio)

Tabel 3

Cutoff prediksi kebangkrutan Zmijewski

\begin{tabular}{ccc}
\hline No & Cutoff & Keterangan \\
\hline 1 & $\mathrm{Z}>0$ & Bangkrut \\
2 & $\mathrm{Z}<0$ & Tidak Bangkrut/Sehat \\
\hline
\end{tabular}

Sumber: Zmijewski (dalam Dinarjito 2018)

c. Model Prediksi Springate

Prediksi kebangkrutan dengan model ini memiliki formula:

$$
S=1,03 A+3,07 B+0,66 C+0,4 D
$$

Keterangan:

$\mathrm{A}=$ Working Capital/Total Asset

$\mathrm{B}=$ Net profit before interest and texes (EBIT)/Total Asset

$\mathrm{C}=$ Net profit before taxes (EBT)/Current Liabilities

$\mathrm{D}=$ Sales/Total Asset

Tabel 4

Cutoff prediksi kebangkrutan Springate

\begin{tabular}{ccc}
\hline No & Cutoff & Keterangan \\
\hline 1 & $S<0,862$ & Bangkrut \\
2 & $S>0,862$ & Tidak Bangkrut/Sehat \\
\hline Sumber: Springate, G. 1978 (dalam Wulandari et al. 2014)
\end{tabular}


d. Model Prediksi Grover

Prediksi kebangkrutan dengan model ini memiliki formula:

Keterangan:

Score $=1,650 \times 1+3,404 \times 3-0,016 R O A+0,057$

$\mathrm{X} 1=$ Working Capital/Total Assets

$\mathrm{X} 3=$ Earning before interest and taxes (EBIT)/Total Assets

ROA = Net Income/Total Assets

Tabel 5

Cutoff prediksi kebangkrutan Model Grover

\begin{tabular}{ccc}
\hline No & Cutoff & Keterangan \\
\hline 1 & $Z \leq-0,02$ & Bangkrut \\
2 & $Z \geq 0,01$ & Tidak Bangkrut/Sehat \\
\hline
\end{tabular}

Sumber: Grover, 2001 (dalam Rachaprima 2015)

e. Model Prediksi Fulmer

Prediksi kebangkrutan dengan model ini memiliki formula:

$\mathrm{H}=5,528 \mathrm{~V} 1+0,212 \mathrm{~V} 2+0,073 \mathrm{~V} 3+1,270 \mathrm{~V} 4-0,120 \mathrm{~V} 5+$

2,335V6 + 0,575V7 + 1,083V8 + 0,894V9-6,075

Keterangan:

V1 = Retained Earning/Total Assets

$\mathrm{V} 2=$ Sales/Total Assets

$\mathrm{V} 3=$ EBT/Total Equity

V4= Cash Flow from operation/Total Debt

V5 $=$ Total Debt/Total Asset

V6 $=$ Current Liabilities/Total Assets

V7 $=$ Log (Average Tangible Assets)

V8 $=$ Working Capital/Total Debt

V9 $=\log (E B I T) /$ Interest Expense

Tabel 6

Cutoff prediksi kebangkrutan Fulmer

\begin{tabular}{ccc}
\hline No & Cutoff & Keterangan \\
\hline 1 & $\mathrm{H}<0$ & Bangkrut \\
2 & $\mathrm{H}>0$ & Tidak Bangkrut/Sehat \\
\hline Sumber: Fulmer, & 1984 (dalam Lukman dan Ahmar 2015)
\end{tabular}




\section{HASIL PENELITIAN DAN PEMBAHASAN}

Objek yang digunakan dalam penelitian ini adalah perusahaan BUMN bidang industri pengolahan tahun 2014-2018, pemilihan sampel didasarkan pada tingkat pembiayaan hutang perusahaan yang semakin meningkat serta laba yang diperoleh perusahaan kecil bahkan pernah mengalami kerugian dibeberapa perusahaan tersebut, selain itu perusahaan telah mengemukakan laporan keuangan secara jelas sehingga memenuhi kebutuhan rasio-rasio yang digunakan.

Berdasarkan Tabel 7 perusahaan mengalami kondisi yang berbedabeda yaitu sehat, grey area, dan bangkrut, namun keadaan perusahaan didominasi oleh kebangkrutan dan grey area, yang artinya kondisi perusahaan atau kinerja perusahaan belum maksimal dan memungkinkan terjadi financial distress. Berdasarkan penelitian Alkhatib and Al Bzour (2011) model altman merupakan model paling relevan dalam memprediksi kebangkrutan. Perusahaan yang mengalami financial distress pada model ini adalah perusahaan dengan kode saham KRAS dan INAF selama 20142018, KAEF dan SMBR selama 2017-2018, kemudian SMGR pada tahun 2017.

Tabel 7

Hasil Prediksi Kebangkrutan Altman

\begin{tabular}{|c|c|c|c|c|c|}
\hline ALTMAN & KAEF & INAF & SMGR & SMBR & KRAS \\
\hline 2014 & $\begin{array}{r}2,50 \\
\text { (grey }\end{array}$ & $\begin{array}{c}1,624825 \\
\text { (bangkrut) }\end{array}$ & $\begin{array}{l}22 \\
)\end{array}$ & $\begin{array}{l}6,8607 \\
\text { (sehat) }\end{array}$ & $\begin{array}{l}426 \\
\text { rut) }\end{array}$ \\
\hline 2015 & $\begin{array}{c}2,541474 \\
\text { (grey area) }\end{array}$ & $\begin{array}{c}1,442356 \\
\text { (bangkrut) }\end{array}$ & $\begin{array}{r}2,73 \mathrm{~s} \\
\text { (ser }\end{array}$ & $\begin{array}{l}23 \\
t)\end{array}$ & $\begin{array}{l}725 \\
\text { rut) }\end{array}$ \\
\hline 2 & $\begin{array}{c}2,082142 \\
\text { (grey area) }\end{array}$ & $\begin{array}{l}1,621051 \\
\text { (bangkrut) }\end{array}$ & $\begin{array}{c}2,382462 \\
\text { (grey area) }\end{array}$ & $\begin{array}{c}1,94133 \\
\text { (grey area) }\end{array}$ & $\begin{array}{l}0,906629 \\
\text { (bangkrut) }\end{array}$ \\
\hline 2017 & $\begin{array}{c}1,722029 \\
\text { (bangkrut) }\end{array}$ & $\begin{array}{c}1,333055 \\
\text { (bangkrut) }\end{array}$ & $\begin{array}{c}1,801947 \\
\text { (bangkrut) }\end{array}$ & $\begin{array}{c}1,5622 \\
\text { (bangkt) }\end{array}$ & $\begin{array}{c}0,668965 \\
\text { (bangkrut) }\end{array}$ \\
\hline 2018 & $\begin{array}{l}1,369528 \\
\text { (bangkrut) }\end{array}$ & $\begin{array}{c}1,420577 \\
\text { (bangkrut) }\end{array}$ & $\begin{array}{c}2,016986 \\
\text { (grey area) }\end{array}$ & $\begin{array}{c}1,49091 \\
\text { (bangkrut) }\end{array}$ & $\begin{array}{l}0,672811 \\
\text { (bangkrut) }\end{array}$ \\
\hline Rata-rata & $\begin{array}{c}2,044431 \\
\text { (grey area) }\end{array}$ & $\begin{array}{c}1,488373 \\
\text { (bangkrut) }\end{array}$ & $\begin{array}{c}2,379052 \\
\text { (grey area) }\end{array}$ & $\begin{array}{c}3,42308 \\
\text { (sehat) }\end{array}$ & $\begin{array}{c}0,760911 \\
\text { (bangkrut) }\end{array}$ \\
\hline
\end{tabular}

Sedangkan perusahaan dengan kategori sehat terdapat pada perusahaan SMGR dan SMBR 2014-2015, namun setelah periode tersebut perusahaan mengalami penurunan bahkan sampai pada kondisi bangkrut. Adapun kondisi grey area didominasi oleh perusahaan KAEF tiga tahun 
berturut-turut yaitu tahun 2014-2016, namun mengalami penurunan pada tahun setelahnya. Selain KAEF perusahaan SMGR dan SMBR juga pernah berada pada kondisi grey area tahun 2016 dan 2018 untuk SMGR dan hanya di tahun 2016 untuk SMBR.

Gambar 2 memperlihatkan bahwa perusahaan tersehat terdapat pada SMBR dengan nilai diawal tahun penelitian jauh diatas perusahaan lainnya, namun perlahan menurun ditahun berikutnya, sedangkan perusahaan dengan kinerja kurang baik yaitu perusahaan KRAS karena berada diposisi paling rendah diantara semuanya.

Kestabilan perusahaan dirasa stabil cenderung menurun pada perusahaan selain SMBR ditandai dengan adanya penurunan nilai perusahaan secara bertahap dari tahun ke tahun. adapun perusahaan SMBR mengalami ketidakstabilan tergambarkan dari tidak konsistennya mempertahankan kinerja.

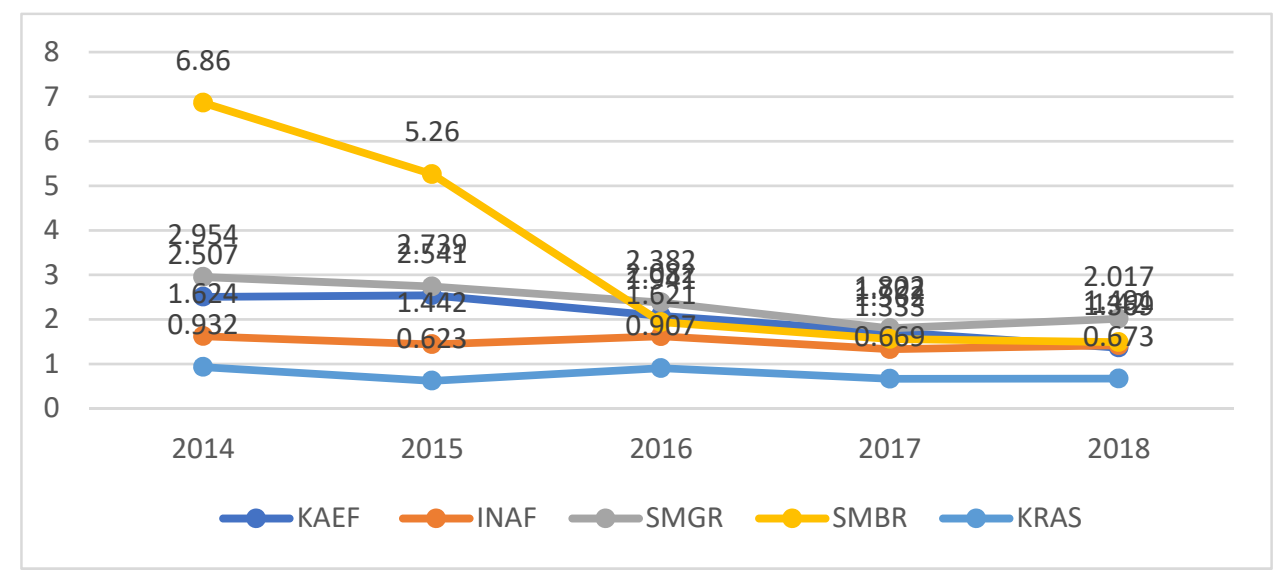

Gambar 2

Stabilitas Perusahaan dengan Model Altman

Sumber: diolah 


\section{Tabel 8}

Hasil Prediksi Kebangkrutan Zmijewski

\begin{tabular}{llllll}
\hline ZMIJEWSKI & KAEF & INAF & SMGR & SMBR & KRAS \\
\hline 2014 & 2,25084 & $-1,29083$ & $-3,49012$ & $-4,44956$ & $-0,27557$ \\
& (sehat) & (sehat) & (sehat) & (sehat) & (sehat) \\
2015 & $-2,36834$ & $-0,8271$ & $-3,23975$ & $-4,26381$ & $-0,95849$ \\
& (sehat) & (sehat) & (sehat) & (sehat) & (sehat) \\
2016 & $-1,67873$ & $-0,92359$ & $-3,00697$ & -294994 & $-2,32371$ \\
& (sehat) & (sehat) & (sehat) & (sehat) & (sehat) \\
2017 & $-1,25639$ & $-0,42932$ & $-2,24785$ & $-2,5814$ & $-1,07568$ \\
& (sehat) & (sehat) & (sehat) & (sehat) & (sehat) \\
2018 & $-0,81911$ & $-0,46475$ & $-2,52686$ & $-2,24559$ & $-0,90896$ \\
& (sehat) & (sehat) & (sehat) & (sehat) & (sehat) \\
Rata-rata & $-1,67468$ & $-0,78712$ & $-2,90231$ & $-3,29806$ & $-1,10848$ \\
& (sehat) & (sehat) & (sehat) & (sehat) & (sehat)
\end{tabular}

Berdasarkan perhitungan pada Tabel 8 nilai zmijewski dari tahun 2014-2018 berada lebih rendah dari 0, artinya dapat dinyatakan seluruh perusahaan berada pada kondisi sehat dan tidak diprediksi mengalami kebangkrutan selama periode penelitian. Husein dan Pambekti (2014) Mengatakan bahwa model zmijewski memiliki tingkat akurasi tertinggi dari model lain dalam penelitiannya, dan model ini dapat digunakan pada penelitian yang berfokus pada leverage sebagai indikator perhitungan.

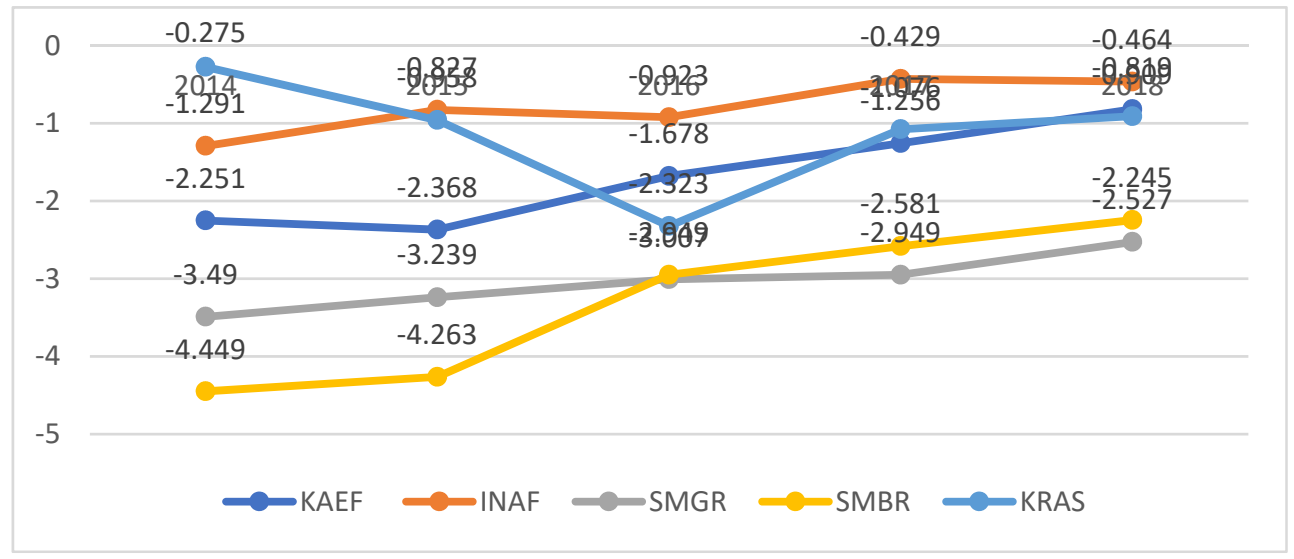

\section{Gambar 3 \\ Stabilitas Perusahaan dengan Model Zmijewski Sumber: diolah}

Pada Gambar 3 posisi SMBR tetap mengungguli perusahaan lain, meskipun seluruh perusahaan yang dijadikan sampel berada pada posisi sehat. Adapun posisi terendah dari model ini dimiliki oleh perusahaan KRAS pada awal tahun 2014, akan tetapi KRAS tumbuh membaik ditahun berikutnya hingga melampaui INAF dan KAEF. 
Dari lima perusahaan dalam model ini, KRAS dinyatakan kurang stabil dalam rentang waktu lima tahun karena perusahaan tersebut pada 2016 mengalami pertumbuhan yang signifikan dari tahun sebelumnya akan tetapi menurun kembali pada tahun setelahnya, adapun empat perusahaan lainnya dinyatakan stabil cenderung menurun tetapi tetap berada pada posisi dibawah nilai 0 , yang artinya perusahaan masih tergolong sehat.

Tabel 9

Hasil Prediksi Kebangkrutan Springate

\begin{tabular}{|c|c|c|c|c|c|}
\hline SPRINGATE & KAEF & INAF & SMGR & SMBR & KRAS \\
\hline 2014 & $\begin{array}{l}0,838458 \\
\text { (bangkrut) }\end{array}$ & $\begin{array}{l}0,415165 \\
\text { (bangkrut) }\end{array}$ & $\begin{array}{l}1,6478 \\
\text { (sehat) }\end{array}$ & $\begin{array}{l}\text { 2,62907 } \\
\text { (sehat) }\end{array}$ & $\begin{array}{l}0,258328 \\
\text { (bangkrut) }\end{array}$ \\
\hline 2015 & $\begin{array}{l}0,827536 \\
\text { (bangkrut) }\end{array}$ & $\begin{array}{l}0,395296 \\
\text { (bangkrut) }\end{array}$ & $\begin{array}{l}1,259143 \\
\text { (sehat) }\end{array}$ & $\begin{array}{l}\text { 2,266307 } \\
\text { (sehat) }\end{array}$ & $\begin{array}{l}0,002547 \\
\text { (bangkrut) }\end{array}$ \\
\hline 2016 & $\begin{array}{l}0,677425 \\
\text { (bangkrut) }\end{array}$ & $\begin{array}{l}0,37234 \\
\text { (bangkrut) }\end{array}$ & $\begin{array}{l}0,971901 \\
\text { (sehat) }\end{array}$ & $\begin{array}{l}1,287755 \\
\text { (sehat) }\end{array}$ & $\begin{array}{l}0,09617 \\
\text { (bangkrut) }\end{array}$ \\
\hline 2017 & $\begin{array}{l}0,587069 \\
\text { (bangkrut) }\end{array}$ & $\begin{array}{l}0,350573 \\
\text { (bangkrut) }\end{array}$ & $\begin{array}{l}0,479734 \\
\text { (bangkrut) }\end{array}$ & $\begin{array}{l}0,537938 \\
\text { (bangkrut) }\end{array}$ & $\begin{array}{l}0,226138 \\
\text { (bangkrut) }\end{array}$ \\
\hline 2018 & $\begin{array}{l}0,49847 \\
\text { (bangkrut) }\end{array}$ & $\begin{array}{l}0,447992 \\
\text { (bangkrut) }\end{array}$ & $\begin{array}{l}0,716912 \\
\text { (bangkrut) }\end{array}$ & $\begin{array}{l}0,566365 \\
\text { (bangkrut) }\end{array}$ & $\begin{array}{l}0,27314 \\
\text { (bangkrut) }\end{array}$ \\
\hline Rata-rata & $\begin{array}{l}0,685792 \\
\text { (bangkrut) }\end{array}$ & $\begin{array}{l}0,396273 \\
\text { (bangkrut) }\end{array}$ & $\begin{array}{l}1,015098 \\
\text { (sehat) }\end{array}$ & $\begin{array}{l}1,457487 \\
\text { (sehat) }\end{array}$ & $\begin{array}{l}0,171265 \text { (b } \\
\text { angkrut) }\end{array}$ \\
\hline
\end{tabular}

Tabel 9 menjelaskan secara spesifik dengan menggunakan model prediksi kebangkrutan springate seluruh perusahaan BUMN pada penelitian ini cenderung mengalami financial distress dengan nilai formula yang dihasilkan dibawah 0,862, hanya ada beberapa perusahaan dan pada periode tertentu saja perusahaan berada pada kondisi sehat. Adapun hasil prediksi springate hampir sama dengan hasil yang diperoleh altman, hanya saja altman membagi kondisi kebangkrutan menjadi tiga keadaan yaitu sehat, grey area, dan bangkrut, sedangkan pada model ini perusahaan dikategorikan berstatus sehat dan bangkrut/distress saja.

Perusahaan-perusahaan yang berada pada kondisi sehat yaitu perusahaan SMGR dan SMBR periode 2014-2016, selain kedua perusahaan tersebut dan pada tahun tersebut perusahaan diprediksi mengalami kebangkrutan. Model ini mempunyai kemiripan dengan model altman sehingga nilai yang dihasilkan menuai persamaan yaitu hanya perusahaan 
SMGR dan SMBR saja yang berada pada kondisi sehat dan sama-sama menyatakan bahwa periode setelahnya mengalami kebangkrutan/distress.

\section{Gambar 4}

\section{Stabilitas Perusahaan dengan Model Springate}

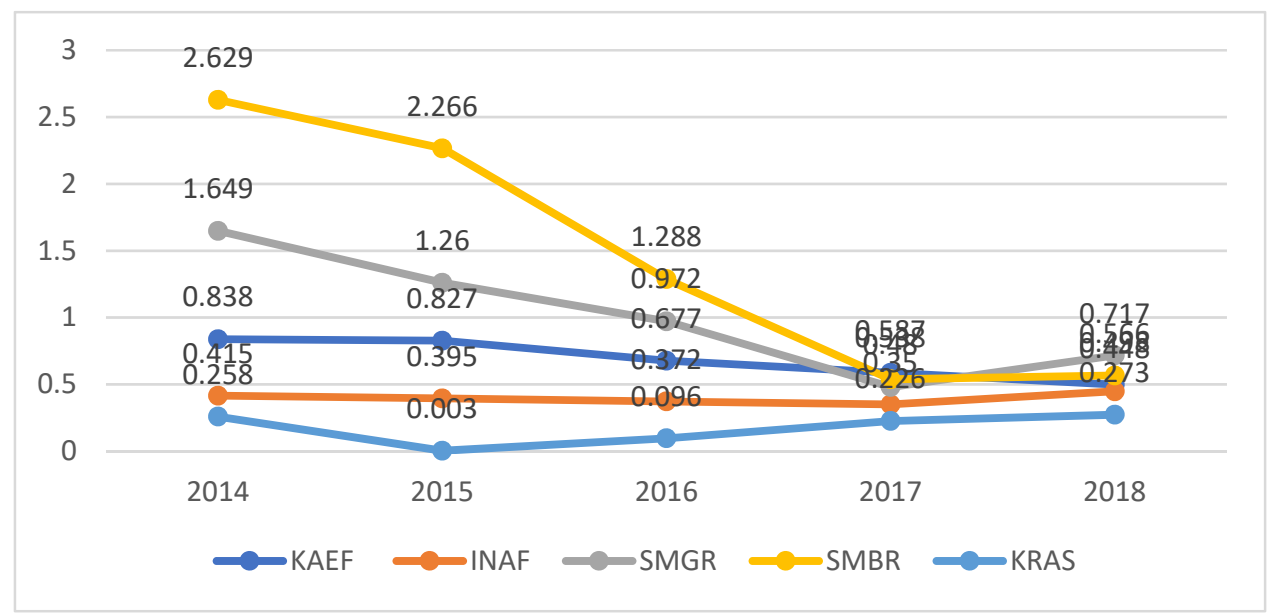

Sumber: diolah

Gambar 4 memperlihatkan hasil yang sama dengan model sebelumnya yaitu perusahaan dengan posisi tertinggi masih dimiliki oleh perusahaan SMBR, namun kinerja yang baik tidak bisa dipertahankan oleh SMBR sehingga perusahaan tersebut hanya mampu bertahan dengan status sehat dalam tiga tahun saja, kemudian setelah tahun 2016 kedua perusahaan tersebut berstatus bangkrut. Dengan model ini KRAS kembali menjadi perusahaan dengan posisi terendah dibanding perusahaan lainya.

Kestabilan selama periode penelitian terlihat stabil cenderung menurun karena kestabilan tersebut berada dibawah cutoff, hanya perusahaan SMGR dan SMBR yang mengalami penurunan yang sangat drastis menjadi distress pada tahun 2017-2018 dimana pada tahun sebelumnya mengalami kondisi yang sangat baik.

Berdasarkan hasil perhitungan Tabel 10 perusahaan menggunakan model grover dominan berada pada kondisi sehat, tiga perusahaan dipresiksi berada pada kondisi tersebut, sedangkan dua lainnya berada pada kondisi yang berbeda-beda. Dalam penelitian ini peneliti menambahkan kategori grey area untuk kondisi antara sehat dan bangkrut karena pengolahan data yang dihasilkan memperoleh nilai $-0,02<Z<0,01$ sehingga perlu dicantumkannya keadaan antara dua kondisi tersebut seperti pada model altman.

Adapun perusahaan yang memiliki nilai cutoffkurang dari atau sama dengan - 0,02 adalah perusahaan KAEF dan INAF 2014-2016, tetapi periode setelahnya mengalami pertumbuhan yang baik sehingga berstatus sehat. Sedangkan perusahaan yang menghasilkan nilai cutoff lebih tinggi dari atau sama dengan 0,01 adalah perusahaan SMGR, SMBR, dan KRAS selama periode penelitian. Adapun perusahaan KAEF 2017 dan INAF 2017 berada 
diantara nilai cutoff maka kondisi tersebut termasuk dalam kategori aman/grey area seperti yang diterapkan pada model altman.

Tabel 10

Hasil Prediksi Kebangkrutan Grover

\begin{tabular}{|c|c|c|c|c|c|}
\hline GROVER & KAEF & INAF & SMGR & SMBR & KRAS \\
\hline 2014 & $\begin{array}{l}-0,17465 \\
\text { (bangkrut) }\end{array}$ & $\begin{array}{l}-0,0565 \\
\text { (bangkrut) }\end{array}$ & $\begin{array}{l}0,456091 \\
\text { (sehat) }\end{array}$ & $\begin{array}{l}1,553676 \\
\text { (sehat) }\end{array}$ & $\begin{array}{l}0,190042 \\
\text { (sehat) }\end{array}$ \\
\hline 2015 & $\begin{array}{l}-0,04106 \\
\text { (bangkrut) }\end{array}$ & $\begin{array}{l}-0,05937 \\
\text { (bangkrut) }\end{array}$ & $\begin{array}{l}0,436697 \\
\text { (sehat) }\end{array}$ & $\begin{array}{l}1,252017 \\
\text { (sehat) }\end{array}$ & $\begin{array}{l}0,145039 \\
\text { (sehat) }\end{array}$ \\
\hline 2016 & $\begin{array}{l}-0,05017 \\
\text { (bangkrut) }\end{array}$ & $\begin{array}{l}-0,03786 \\
\text { (bangkrut) }\end{array}$ & $\begin{array}{l}0,388939 \\
\text { (sehat) }\end{array}$ & $\begin{array}{l}0,518146 \\
\text { (sehat) }\end{array}$ & $\begin{array}{l}0,156747 \\
\text { (sehat) }\end{array}$ \\
\hline 2017 & $\begin{array}{l}0,005381 \\
\text { (grey area) }\end{array}$ & $\begin{array}{l}0,007302 \\
\text { (grey area) }\end{array}$ & $\begin{array}{l}0,097892 \\
\text { (sehat) }\end{array}$ & $\begin{array}{l}0,334042 \\
\text { (sehat) }\end{array}$ & $\begin{array}{l}0,235752 \\
\text { (sehat) }\end{array}$ \\
\hline 2018 & $\begin{array}{l}0,053358 \\
\text { (sehat) }\end{array}$ & $\begin{array}{l}0,072461 \\
\text { (sehat) }\end{array}$ & $\begin{array}{l}0,141169 \\
\text { (sehat) }\end{array}$ & $\begin{array}{l}0,423995 \\
\text { (sehat) }\end{array}$ & $\begin{array}{l}0,28842 \\
\text { (sehat) }\end{array}$ \\
\hline Rata-rata & $\begin{array}{l}-0,04143 \\
\text { (bangkrut) }\end{array}$ & $\begin{array}{l}-0,01479 \\
\text { (grey area) }\end{array}$ & $\begin{array}{l}0,304158 \\
\text { (sehat) }\end{array}$ & $\begin{array}{l}0,816375 \\
\text { (sehat) }\end{array}$ & $\begin{array}{l}0,2032 \\
\text { (sehat) }\end{array}$ \\
\hline
\end{tabular}

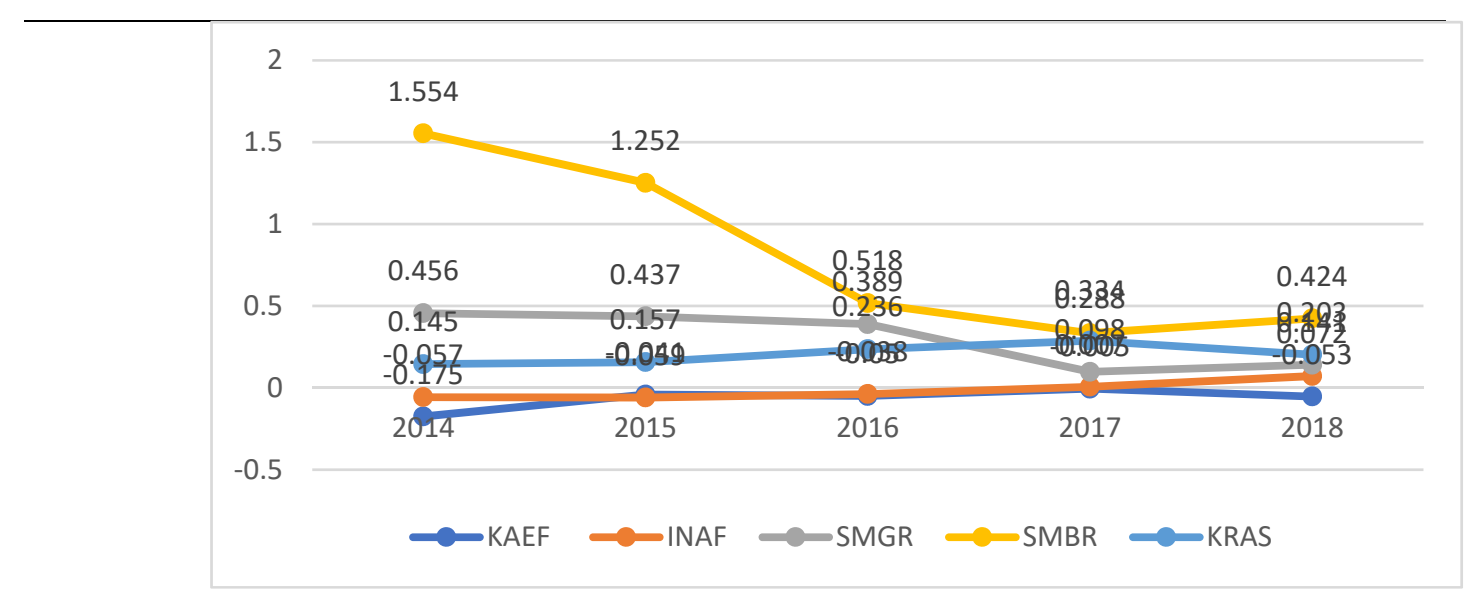

\section{Gambar 5}

Stabilitas Perusahaan dengan Model Grover

Sumber: diolah

Gambar 5 menujukan bahwa perusahaan paling unggul masih dimiliki oleh perusahaan SMBR, sedangkan kinerja buruk terdapat pada dua perusahaan lainnya yaitu KAEF dan INAF dimana keduanya berada dibawah nilai cutoff periode 2014-2016 tetapi mengalami kenaikan di tahun setelahnya.

Terdapat ketidakstabilan pada perusahaan SMBR, nilai SMBR pada awal tahun penelitian berada diatas perusahaan lainnya, namun terjadi penurunan yang sangat drastis pada tahun 2016-2018. Adapun perusahaan lainnya terlihat stabil pada nilai yang sama dari tahun ke tahun. 
Hasil perhitungan Tabel 11 menyatakan bahwa seluruh perusahaan selama periode penelitian mengalami kondisi sehat, artinya nilai yang dihasilkan perusahaan selalu berada lebih tinggi dari nilai cutoff. Hasil penelitian ini sama seperti hasil pada model zmijewski yang mendapati keseluruhan sampel berada pada kondisi sehat.

Tabel 11

Hasil Prediksi Kebangkrutan Fulmer

\begin{tabular}{|c|c|c|c|c|c|}
\hline FULMER & KAEF & INAF & SMGR & SMBR & KRAS \\
\hline 2014 & $\begin{array}{l}, 195907 \\
\text { (sehat) }\end{array}$ & $\begin{array}{l}2,769866 \\
\text { (sehat) }\end{array}$ & $\begin{array}{l}3,939217 \\
\text { (sehat) }\end{array}$ & & $\begin{array}{l}1,212301 \\
\text { (sehat) }\end{array}$ \\
\hline 2015 & $\begin{array}{l}3,449238 \\
\text { (sehat) }\end{array}$ & $\begin{array}{l}2,711373 \\
\text { (sehat) }\end{array}$ & $\begin{array}{l}\text { 4,357339 } \\
\text { (sehat) }\end{array}$ & $\begin{array}{l}8,94637 \\
\text { (sehat) }\end{array}$ & $\begin{array}{l}0,634676 \\
\text { (sehat) }\end{array}$ \\
\hline 2016 & $\begin{array}{l}3,455821 \\
\text { (sehat) }\end{array}$ & $\begin{array}{l}2,025735 \\
\text { (sehat) }\end{array}$ & $\begin{array}{l}4,108462 \\
\text { (sehat) }\end{array}$ & $\begin{array}{l}1,6184 \\
\text { (sehat) }\end{array}$ & $\begin{array}{l}0,278713 \\
\text { (sehat) }\end{array}$ \\
\hline 2017 & $\begin{array}{l}3,404658 \\
\text { (sehat) }\end{array}$ & $\begin{array}{l}2,782895 \\
\text { (sehat) }\end{array}$ & $\begin{array}{l}3,334729 \\
\text { (sehat) }\end{array}$ & $\begin{array}{l}1,55135 \\
\text { (sehat) }\end{array}$ & $\begin{array}{l}0,237224 \\
\text { (sehat) }\end{array}$ \\
\hline 2018 & $\begin{array}{l}3,203705 \\
\text { (sehat) }\end{array}$ & $\begin{array}{l}2,405132 \\
\text { (sehat) }\end{array}$ & $\begin{array}{l}3,379618 \\
\text { (sehat) }\end{array}$ & $\begin{array}{l}1,39099 \\
\text { (sehat) }\end{array}$ & $\begin{array}{l}0,266132 \\
\text { (sehat) }\end{array}$ \\
\hline Rata-rata & $\begin{array}{l}\text { 3,341866 } \\
\text { (sehat) }\end{array}$ & $\begin{array}{c}2,539 \\
\text { (sehat) }\end{array}$ & $\begin{array}{l}3,823873 \\
\text { (sehat) }\end{array}$ & $\begin{array}{l}5,38365 \\
\text { (sehat) }\end{array}$ & $\begin{array}{l}0,525809 \\
\text { (sehat) }\end{array}$ \\
\hline
\end{tabular}

Nilai fulmer tertinggi masih diperoleh perusahaan SMBR dengan nilai pada 2014 jauh diatas perusahaan-perusahaan lainnya, SMBR memiliki nilai paling tinggi yaitu 13,411 sedangkan cutoff untuk model ini adalah 0 , dan perusahaan dengan kinerja kurang optimal pada penelitian ini adalah perusahaan KRAS dibuktikan dengan posisinya yang rendah dari beberapa model prediksi kebangkrutan.

Tren pertumbuhan fulmer dari tahun 2014-2018 berada pada posisi stabil, penurunan yang dialami perusahaan tidak mencapai posisi bangkrut hanya saja perusahaan KRAS mendekati titik 0 pada tahun 2016-2018, sedangkan ketidakstabilan perusahaan terjadi pada SMBR karena mengalami menurun jauh sekali pada tahun-tahun setelahnya 2015.

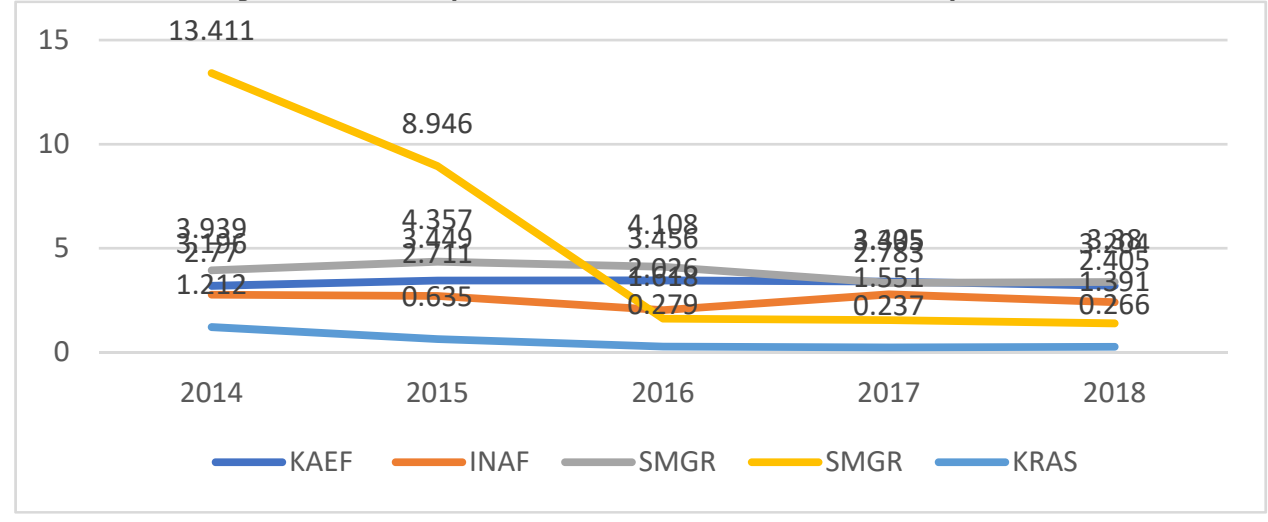




\section{Gambar 5 \\ Stabilitas Perusahaan dengan Model Grover \\ Sumber: diolah}

Tabel 12

Hasil Prediksi Kebangkrutan Fulmer

\begin{tabular}{|c|c|c|c|c|c|}
\hline Rata-rata & ALTMAN & ZMJWSK & SPRNGT & GROVER & FULMER \\
\hline KAEF & $\begin{array}{l}2,044431 \\
\text { (grey area) }\end{array}$ & $\begin{array}{l}-1,67468 \\
\text { (sehat) }\end{array}$ & $\begin{array}{l}0,685792 \\
\text { (bangkrut) }\end{array}$ & $\begin{array}{l}-0,04143 \\
\text { (bangkrut) }\end{array}$ & $\begin{array}{l}\text { 3,341866 } \\
\text { (sehat) }\end{array}$ \\
\hline INAF & $\begin{array}{l}1,488372536 \\
\text { (bangkrut) }\end{array}$ & $\begin{array}{l}-0,78712 \\
\text { (sehat) }\end{array}$ & $\begin{array}{l}0,396273 \\
\text { (bangkrut) }\end{array}$ & $\begin{array}{l}-0,01479 \\
\text { (grey area) }\end{array}$ & $\begin{array}{l}2,539 \\
\text { (sehat) }\end{array}$ \\
\hline SMGR & $\begin{array}{l}2,379051533 \\
\text { (grey area) }\end{array}$ & $\begin{array}{l}-2,90231 \\
\text { (sehat) }\end{array}$ & $\begin{array}{l}1,015098 \\
\text { (sehat) }\end{array}$ & $\begin{array}{l}0,304158 \\
\text { (sehat) }\end{array}$ & $\begin{array}{l}3,823873 \\
\text { (sehat) }\end{array}$ \\
\hline SMBR & $\begin{array}{l}3,423077262 \\
\text { (sehat) }\end{array}$ & $\begin{array}{l}-3,29806 \\
\text { (sehat) }\end{array}$ & $\begin{array}{l}1,457487 \\
\text { (sehat) }\end{array}$ & $\begin{array}{l}0,816375 \\
\text { (sehat) }\end{array}$ & $\begin{array}{l}5,383652 \\
\text { (sehat) }\end{array}$ \\
\hline KRAS & $\begin{array}{l}0,76091113 \\
\text { (bangkrut) }\end{array}$ & $\begin{array}{l}-1,10848 \\
\text { (sehat) }\end{array}$ & $\begin{array}{l}0,171265 \\
\text { (bangkrut) }\end{array}$ & $\begin{array}{l}0,2032 \\
\text { (sehat) }\end{array}$ & $\begin{array}{l}0,525809 \\
\text { (sehat) }\end{array}$ \\
\hline
\end{tabular}

Berdasarkan Tabel 12 nilai rata-rata altman memprediksi perusahaan bangkrut terdapat pada perusahaan INAF dan KRAS, grey area terdapat pada KAEF dan SMGR, sedangkan perusahaan sehat hanya dimiliki oleh SMBR. Adapun hasil perhitungan rata-rata springate tidak jauh berbeda seperti hasil altman hanya menambah perusahaan bangkrut menjadi 3 perusahaan diantaranya KAEF, INAF, dan KRAS, dan perusahaan dengan hasil nilai rata-rata sehat terdapat pada perusahaan SMGR dan SMBR. Model grover berbeda dengan kedua model diatas dimana hasil rata-rata grover menunjukkan hanya 1 perusahaan bangkrut yaitu KAEF, 1 perusahaan berada diposisi grey area, dan 3 perusahaan lain berada pada kondisi sehat. Sedangkan model zmijewski dan fulmer menghasilkan nilai rata-rata perusahaan dalam keadaan sehat.

Berdasarkan semua perhitungan model prediksi kebangkrutan yang telah dilakukan, dapat disimpulkan bahwa model yang menghasilkan prediksi sehat yaitu model zmijewski dan fulmer dengan presentase dominasi $100 \%$ sehat, diikuti grover dengan presentase $68 \%$ perusahaan sehat. Sedangkan model prediksi yang menghasilkan perusahaan dominan bangkrut yaitu model altman dan springate dinyatakan dalam presentase yaitu $60 \%$ untuk model altman dan $76 \%$ untuk model springate dari keseluruhan perusahaan, namun menurut Aminian et al. (2016) seluruh model tersebut signifikan untuk dijadikan model prediksi kebangkrutan 
dengan koefisien determinasi berturut-turut dari yang paling signifikan yaitu grover, altman, springate, dan zmijweski.

Adapun tingkat kesehatan perusahaan dilihat dari 5 model tersebut dapat disimpulkan bahwa perusahaan dengan kategori tersehat berturutturut yaitu perusahaan Semen Baturaja (Persero) Tbk, Semen Indonesia (Persero) Tbk, Krakatau Steel (Persero) Tbk, Kimia Farma (Persero) Tbk, Indofarma (Persero) Tbk.

\section{SIMPULAN}

Berdasarkan hasil prediksi kebangkrutan menggunakan model altman, zmijewski, springate, grover, dan fulmer menghasilkan kondisi yang berbeda-beda, pada model altman perusahaan didominasi pada kebangkrutan, hanya perusahaan SMBR dan SMGR yang berada pada kondisi sehat begitu pula pada model springate, sedangkan model zmijewski dan fulmer menyatakan bahwa seluruh perusahaan dalam keadaan sehat, dan diikuti oleh grover dengan sebagian perusahaan sehat dan sebagian yang lain berada pada kondisi grey area dan bangkrut. Tingkat kesehatan perusahaat dari yang tersehat berturut-turut yaitu SMBR, SMGR, KRAS, KAEF, dan INAF.

Penelitian ini memiliki keterbatasan yaitu tidak diterapkannya pengujian akurasi antara model prediksi kebangkrutan, hanya melakukan pengembangan model prediksi kebangkrutan saja. Adapun saran yang diberikan peneliti untuk penelitian selanjutnya yaitu agar mencoba menganalisis kebangkrutan pada BUMN sektor perbankan karena sektor tersebut merupakan BUMN besar dan hutang yang dimiliki termasuk dalam kategori hutang BUMN terbesar.

\section{DAFTAR PUSTAKA}

Alkhatib, K., \& Eqab Al Bzour, A. (2011). Predicting Corporate Bankruptcy of Jordanian Listed Companies: Using Altman and Kida Models. International Journal of Business and Management, 6 (3), 208-215.

Aminian, A., Mousazade, H., \& Khoshkho, O. I. (2016). Investigate the Ability of Bankruptcy Prediction Models of Altman and Springate and Zmijewski and Grover in Tehran Stock Exchange. Mediterranean Journal of Social Sciences, 7(4), 208-214.

Asnita, R., \& Fuadi, R. (2016). Analisis Perbandingan Prediksi Kebangkrutan Perusahaan Dengan Menggunakan Multivariate Discriminant Analysis Dan Regresi Logistik Pada Perusahaan Pertambangan Batubara Periode 2010-2014. Jurnal IImiah Mahasiswa Ekonomi Akuntansi (JIMEKA), 1 (1).

Bestari, R. (2014). Prevensi Budgetary Slack Sebagai Dampak Agensi dengan Metode Reframing Komunikasi Neuro Linguistik Prrogram 
(NLP). Jurnal Akuntansi Unesa, 2 (2).

Dinarjito, A. (2018). Menilai Kesehatan BUMN Konstruksi yang Terdaftar di Bursa Efek Indonesia sebagai Akibat Meningkatnya Proyek InfrastrukturPemerintah. Substansi, 2(1), 1-10.

Fakhri Husein, M., \& Tri Pambekti, G. (2014). Precision of the models of Altman, Springate, Zmijewski, and Grover for predicting the financial distress A R T I C L E I N F O. Journal of Economics, 17(3), 405-416.

Gunawan, B., Pamungkas, R., \& Susilawati, D. (2017). Perbandingan Prediksi Financial Distress Menggunakan Model Altman, Grover dan Zmijewski. Jurnal Akuntansi Dan Investasi, 18(1), 119-127.

Keputusan Menteri Badan Usaha Milik Negara Nomor: SK-16/MBU/01/2016 Tentang Rencana Strategis Kementerian Badan Usaha Milik Negara 2015-2019. , (2015).

Lukman, M., \& Ahmar, N. (2015). Model Prediksi Kebangkrutan Fulmer HScore dan Springate: Mana yang Lebih Kuat? Seminar Nasional Cendekiawan. STIE Perbanas Surabaya: STIE Perbanas Surabaya.

Rachaprima, M. R. (2015). Analisis Komparatif Prediksi Kebangkrutan dengan Model Ohlson, Springate, Zmijewski, dan Grover pada Perusahaan Konstruksi dan Bangunan yang Terdaftar di Bursa Efek Indonesia. Jom FEKON, 2(2), 1-16.

Riswan, \& Affandi, A. (2014). Pengaruh Kinerja Keuangan Daerah terhadap Belanja Modal untuk Pelayanan Publik dalam Perspektif Teori Keagenan (Studi pada Kabupaten/Kota Se-Sumatera). Jurnal Akuntansi \& Keuangan, 5(2), 71-90.

Wibisono, R. T., Nur DP, E., \& Julita. (2014). Analisis Tingkat Kebangkrutan Model Altman, Foster, dan Springate Pada Perusahaan Property and Real Estate Go Public di Bursa Efek Indonesia (Periode 2008-2011). JOM Fekon, 1 (2), 1-15.

Wulandari, V., Nur, E., \& Julita. (2014). Analisis Perbandingan Model Altman, Springate, Ohlson, Fulmer, CA-Score dan Zmijewski Zmijewski Dalam Memprediksi Financial Distress (studi empiris pada Perusahaan Food and Beverages yang Terdaftar di Bursa Efek Indonesia Periode 2010-2012). Jom Fekon, 1 (2), 1-18. 